\title{
Research on the Evolution and Ptotection of Kulangsu Historic International Settlement Under the Influence of Tourism Development
}

\author{
Chenxi Zhao \\ School of Architecture, Southeast University, Nanjing, China
}

Email address:

sylvia_zhao@yeah.net

\section{To cite this article:}

Chenxi Zhao. Research on the Evolution and Ptotection of Kulangsu Historic International Settlement Under the Influence of Tourism Development. Science Discovery. Vol. 9, No. 5, 2021, pp. 244-254. doi: 10.11648/j.sd.20210905.18

Received: September 10, 2021; Accepted: October 18, 2021; Published: October 28, 2021

\begin{abstract}
China has a large number of world cultural heritage sites at present. On the one hand, the rise of tourism can promote the regional economic development. On the other hand, excessive commercialization also challenges the authenticity and integrity of heritage sites. Since Kulangsu has developed tourism since the late 1980s, the cultural ecology of the community has long been overwhelmed by the over-exploitation of tourism. Taking advantage of the opportunity of being registered on list of the world cultural heritage as the "Historic International Settlement" in 2017, meeting the challenges of tourism commercialization and reviving the traditional community has become important issues for Kulangsu in the "Post-Applying for the Heritage Era". This paper, taking the Historic International Settlement of Kulangsu as an example, based on historical literature, through analysis, deduction and induction, first sorts out the historical context and unique values from the aspects of historical development, urban structure, and social economy, and then summarizes the four stages of the community's evolution being influenced by the tourism development, reveals the alienation crisis faced by the community, constructs the development dynamic mechanism of the community. Finally, integrating the value judgment and development dynamic mechanism of Kulangsu, this paper puts forward the future sustainable development strategy of Kulangsu.
\end{abstract}

Keywords: Kulangsu, Historic Settlement, Development of Tourism, Protection, Dynamic Mechanism

\section{旅游开发影响下鼓浪屿历史国际社区演化及保护初探}

\section{赵晨西}

东南大学建筑学院, 南京, 中国

\section{邮箱}

sylvia_zhao@yeah.net

摘要: 当前我国世界文化遗产地数量众多, 一方面, 对遗产地进行旅游开发能推动地区经济发展, 而另一方面, 过度 商业化也对遗产原真性与完整性提出挑战。鼓浪屿自20世纪80年代末起发展旅游业, 社区文化生态早已不堪旅游过度 开发的重负。借助2017年以“历史国际社区”登录世界文化遗产的契机，应对旅游商业化挑战、实现社区复兴则成为鼓 浪屿在“后申遗”时代的重要议题。本文以鼓浪屿历史国际社区为例, 基于历史文献资料, 通过分析、演绎、归纳手段, 首先从发展历程、城市格局、社会经济等方面梳理鼓浪屿历史国际社区的历史脉络与独特价值, 其次归纳旅游开发影 响下鼓浪屿社区演化的四个阶段, 揭示社区面临的异化危机, 建构鼓浪屿社区发展动力机制, 最后综合鼓浪屿价值判 断与发展动力机制针对性地提出鼓浪屿未来可持续发展策略。 
关键词: 鼓浪屿, 历史社区, 旅游开发, 保护, 动力机制

\section{1. 引言：“后申遗”时代历史遗产保护与发展}

位于中国东南沿海、福建省厦门市的鼓浪屿, 因其 19 世纪中叶到 20 世纪中叶特殊的管理模式、文化交流状态以 及由此在住区和景观营造上表现出的独特性和代表性[1], 于2017年7月 8日, 以“鼓浪屿历史国际社区”主题登录世界 文化遗产, 鼓浪屿的发展方向也从强调旅游的景区时代转 变为注重人文的历史社区时代。然而长期以来在“旅游热” 冲击下鼓浪屿社区的人文氛围衰退, 维系社区的精神情感 正逐渐消失，表现为明显的物质性老化和社区空心化，使 鼓浪屿失去了最为原真的人文个性与特色[2]。在“后申遗” 时代, 确定鼓浪屿历史国际社区保护与发展方向, 探寻其 在旅游开发影响下实现可持续发展的路径, 对诸如泉州、 苏州古城等旅游业发达的历史城区具有一定的借鉴意义。

业内学者对此的相关研究集中于鼓浪屿价值认定、旅 游影响评价、社区发展机制等方面。在鼓浪屿遗产价值研 究与保护方面, 吕宁等人对鼓浪屿的发展与演变进行系统 梳理, 深入分析并提炼鼓浪屿价值体系, 肯定了鼓浪屿作 为融合多元文化的国际社区的独特价值[3]。刘宁基于鼓浪 屿文化遗产多维价值, 建立了包括法律保障、价值展示、 旅游管控、公众参与等内容的综合保护体系 [4]。在旅游发 展对鼓浪屿历史社区影响研究方面, 吕宁等人聚焦旅游这 一经济效益, 通过定性、定量分析手段探讨旅游模式转变 对鼓浪屿入遗效应的影响, 并认为整体评价尚需要长期动 态跟踪与数据分析 [1]。赵刚等人分析旅游开发热潮中鼓浪 屿社区发展存在的问题, 剖析社区衰败根源, 提出了宜居 建设、内涵提升、多元管理等社区可持续发展对策[2]。在 社区发展机制研究方面, 曾艾依然运用扎根理论质性研究 方法生成鼓浪屿旅游社区㓞性理论框架，建立旅游社区韧
性综合评价模型，揭示社区韧性影响机理与驱动机制，认 为鼓浪屿目前处于世界文化遗产旅游社区适应性循环的 初始阶段, 并提出适应性管理对策[5]。欧阳邦则对旅游商 业化影响下鼓浪屿社区不同发展阶段的特征与危机进行 分析总结, 剖析出受旅游、经济、环境、政策等因素影响 的鼓浪屿社区变迁机制, 认为社区由封闭性生活空间转变 为开放性消费场所是问题根源, 并从政策、空间与人文层 面提出社区发展相关策略[6]。

本文基于历史文献资料和官方数据统筹, 试图从政策、 经济社会、人口结构、城市空间四个维度分析鼓浪屿历史 社区自 20 世纪 80 年代至今在旅游开发影响下的演化路径, 溯源当前社区发展危机, 构建适用于鼓浪屿的社区发展动 力机制, 以探索鼓浪屿未来可持续发展的路径。

\section{2. 回望：鼓浪屿历史国际社区发展脉络}

\section{1. 鼓浪屿发展历程}

鼓浪屿的发展始于宋末元初, 最早是传统的闽南渔村 聚落; 自鸦片战争爆发、厦门开埠和公共租界确立以来, 众多西方势力和海外华侨陆续登岛进行建设, 成为中外交 流的重要窗口, 鼓浪屿城市格局基本形成于这一“公共租 界”时期, 以其优美的自然环境、宽松的政治氛围、多元 的文化和高品质的社区生活, 吸引了外国人和返乡华侨在 此定居, 在不到百年的时间内, 完成了从传统渔村到殖民 风格居留地再到兼具国际化与本土化特征的现代社区的 跨越发展 [3]。在解放后, 其发展则交织了强景弱城和强城 弱景的不同过程, 从内向性生活城区转变为风景旅游地。

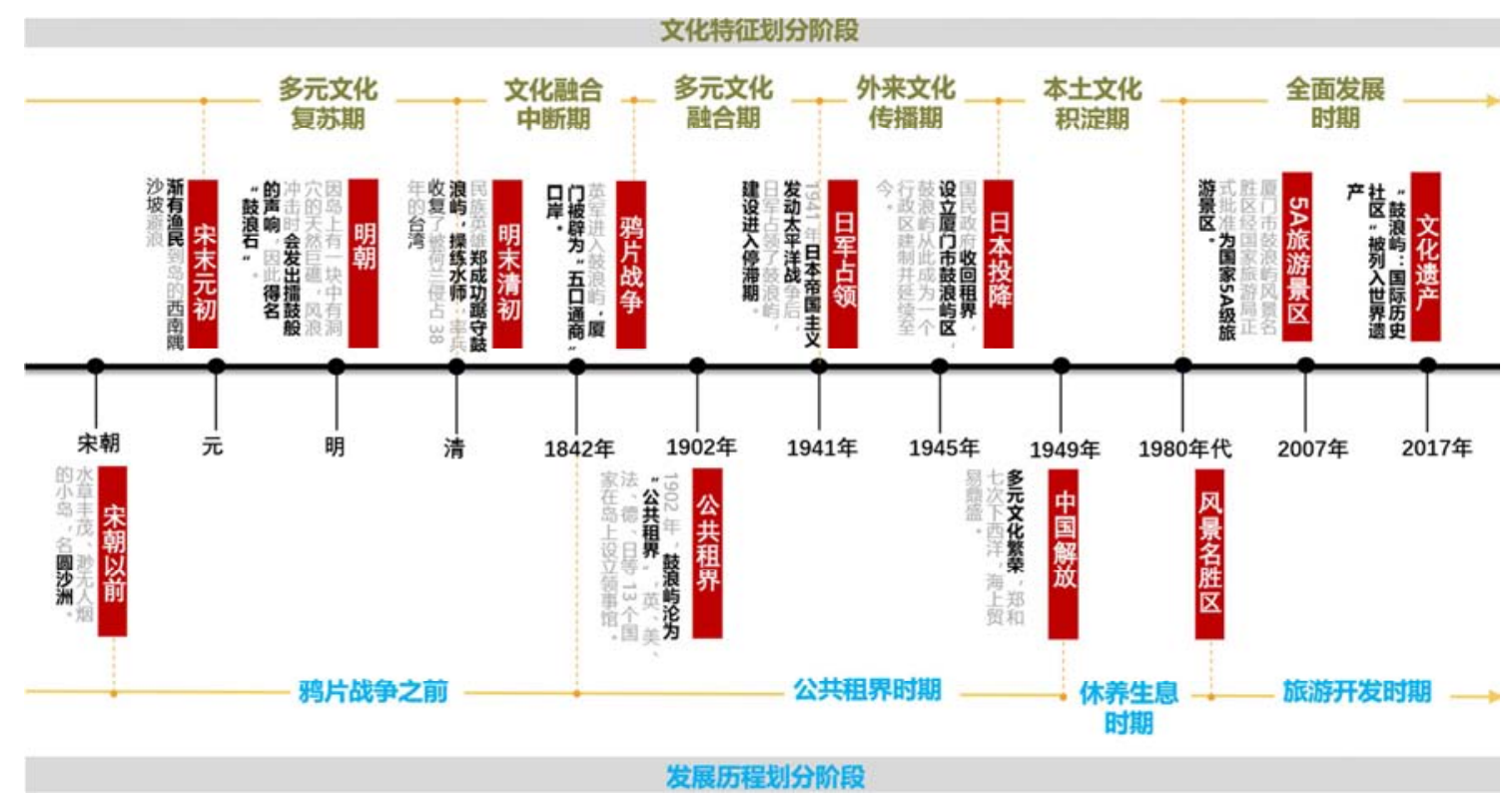

图1 鼓浪屿历史沿革。 


\section{2. 城市格局演化}

鸦片战争后, 众多西方势力进入鼓浪屿, 将西方住区 建设与管理理念集中传播到岛上。受到自然条件的制约, 建设的范围局限在距东部码头不远的龙头路片区, 并在空 间上初步呈现出中西社区的分界。

鼓浪屿的城市肌理基本形成于“公共租界”时期。1903 年至1914年, 公共租界成立初期, 闽台富商受到外部经济 环境不稳定的影响而内迁回厦, 并选择鼓浪屿投资置业。 新的建设力量进入, 打破了鼓浪屿原有的中外居民各自营 建住区的状态。这一时期岛上建设数量依旧相对较少, 近 代住区仍处于萌芽阶段。
1915年至1938年的繁荣期, 鼓浪屿的建设情况有了极 大的转变, 西方人不再是岛屿最重要的建设力量, 这一时 期是鼓浪屿最集中的发展建设时期, 来鼓开展建设的东南 亚华侨群体极为活跃, 鼓浪屿近代住区空间最终确立。

1939年至1945年则是公共租界发展停滞期, 这一时期 由于日本实行的独裁统治, 鼓浪屿住区的建设活动几乎停 滞。直至解放后鼓浪屿住区建设活动始有复苏。, 但是变 化不大。近代以来, 随着2012年西北部内厝澳码头的设立, 内厝澳片区得到快速发展; 而鹿耳礁片区则保持着相对松 散的布局缓慢成长。

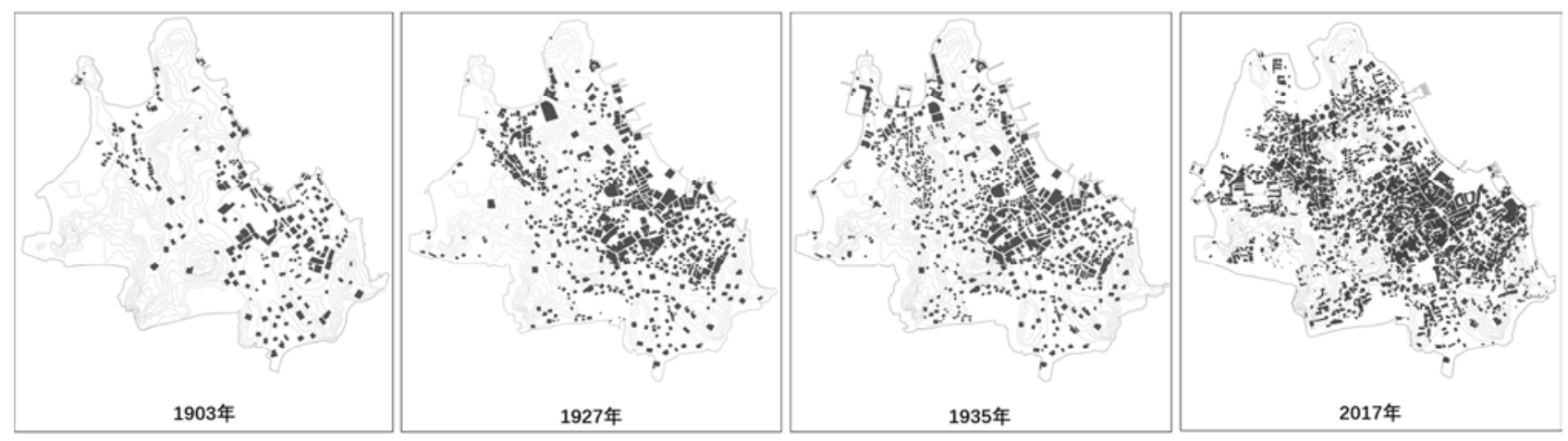

图2 鼓浪屿建成肌理演化。

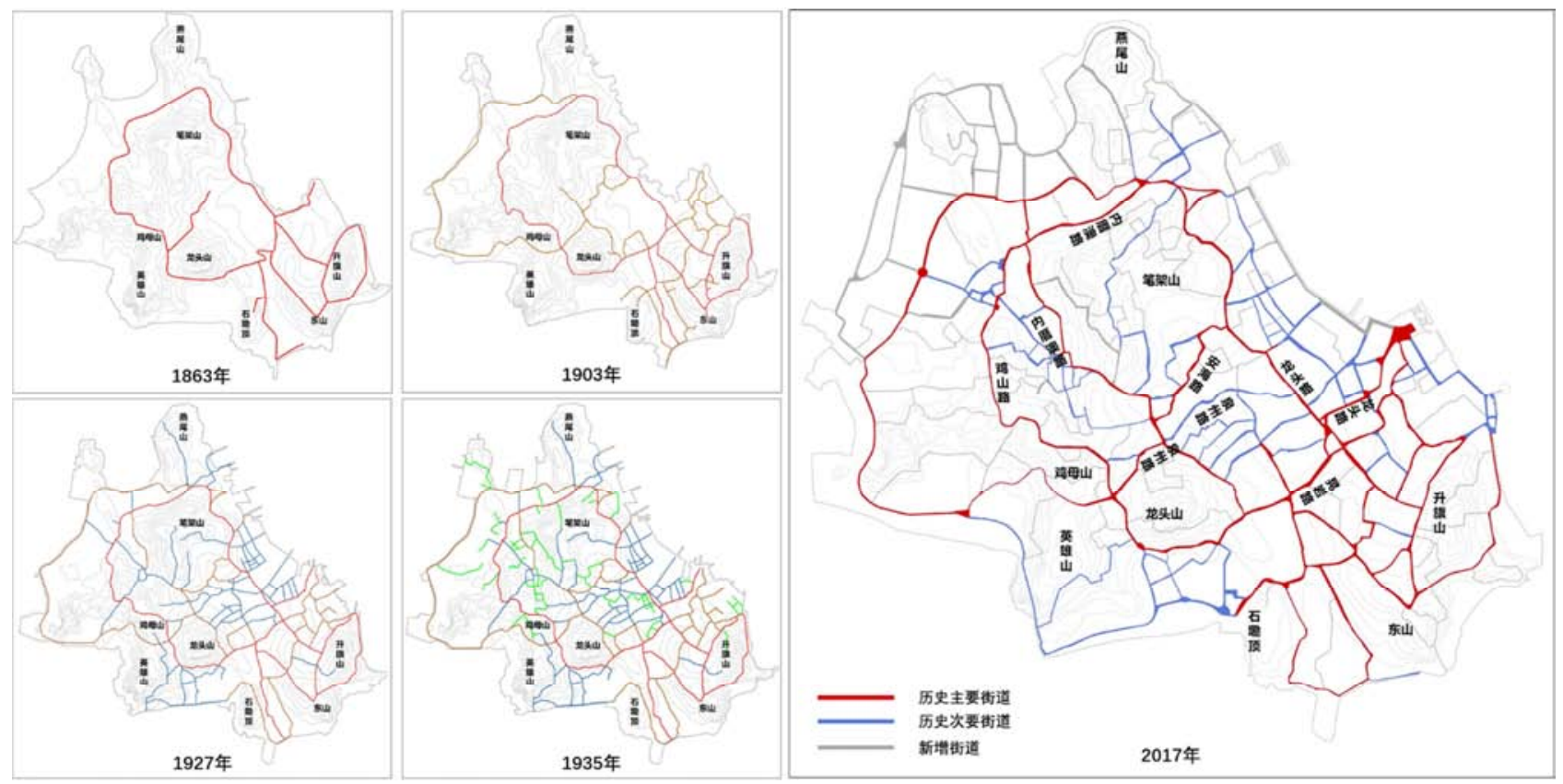

图3 鼓浪屿道路系统演化。

\section{3. 社会经济变迁}

从19世纪起, 鼓浪屿凭借优良的海港地理位置, 借助 中西富商资本, 发展了领先国际的的在地生产文化。20 世纪 50年代以前, 中西方文化在鼓浪屿互相融合, 鼓浪屿 的商贸业快速发展，建设了银行、电报公司、自来水厂等 商贸设施, 并且创办淘化大同酱油厂、水仙花罐头厂、南
洲花砖厂等代表鼓浪屿高水平国际化生产的本地企业。解 放后, 鼓浪屿大力发展工业, 兴建了灯泡厂、玻璃厂、造 船厂等工业设施和配套居住设施, 强化了鼓浪屿作为生活 型社区的职能。而随着 20 世纪 90 年代鼓浪屿大力发展旅游 业以来，逐步实施了产业退二进三、人口疏解等政策。于 是, 鼓浪屿从厦门近代华侨民族工业策源地, 经历抗战时 期民族工商业大后方、新中国出口加工示范龙头地, 最终 
在 2000 年鼓浪屿 16 家工厂全迁出之后, 鼓浪屿传统的在地 生产文化式微。

\begin{tabular}{|c|c|c|c|c|c|}
\hline 1867 & 1893 & 1921 & 1926 & 1929 & 1933 \\
\hline 厦门船坞公司 & 鼓浪屿机器公司 & 南洲花砖厂 & 兆和筴油厂 & 海华大同罐头厂 & 东方汽水厂 \\
\hline
\end{tabular}

\begin{tabular}{|c|c|c|}
\hline 1938 & 1939 & 1945 \\
\hline 鼓浪屿国际救济委员会 & 扩展香港业务 & 老字号食品铺 \\
\hline
\end{tabular}

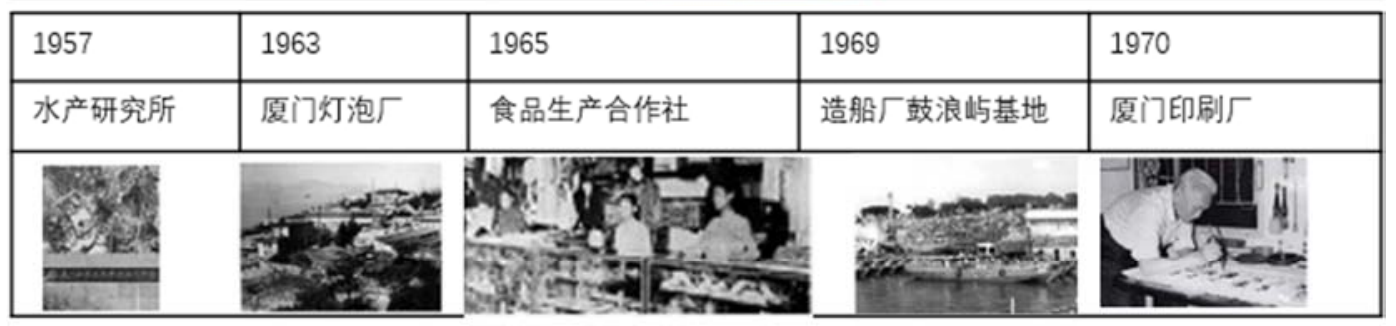

\begin{tabular}{|c|c|c|}
\hline 1997 & 2000 & 2013 \\
\hline 工业生产部门迁至岛外 & 岛内生产基本消失 & 鼓浪屿食品厂回岛打造观光工厂 \\
\hline
\end{tabular}

图4 鼓浪屿在地生产文化兴衰年表。

从历史视角和各方资源的比较来看, 鼓浪屿的优势不 在于优美自然环境的旅游景区，而在于独特的人文社区生 活。鼓浪屿完整的发展历程见证了19世纪到20世纪中叶, 传统社会融入现代公共设施向新社会形态转变的历史变 革，是在多元文化共同影响下发展、完善的近代居住型社 区的独特范例。因此, 鼓浪屿本质上是以生活化为主、文 认同感和包容性强的社区。一味的追求旅游发展而抛弃本 质, 只能带来社区的异化和鼓浪屿的衰败。

\section{3. 时弊：旅游开发视角下鼓浪屿历史社区演化 进程与危机}

\section{1. 旅游开发视角下鼓浪屿历史社区演化}

笔者基于《鼓浪屿商业网点规划（2013）》[7]、《鼓 浪屿文化遗产地保护管理规划（2014）》[8]、《鼓浪屿历 史文化街区保护规划（2014）》[9]、《中国世界遗产预备 名录申报文本: 鼓浪屿（2019）》10]、《鼓浪屿-万石山 风景区总体规划（2017）》[11], 结合2009年至2020年思 明区经济社会年鉴统计数据[12], 从政策、经济社会、人
口结构、城市空间四个维度对旅游开发影响下鼓浪屿历史 社区演化进程进行分析。

\subsection{1. 发展期: 1986年-2003年}

政策方面，1986年出台的《鼓浪屿风景区保护改造规 划》确定了鼓浪屿作为风景区的旅游功能, 之后鼓浪屿万石山风景名胜区成为福建省首批风景名胜区和我国第 二批国家重点风景名胜区, 1995年, 《鼓浪屿-万石山风 景名胜区总体规划》将鼓浪屿作为厦门市旅游行业发展的 主要承载体, 鼓浪屿开始由生活社区转变为旅游景区。经 济社会方面, 这一时期制造产业迁出鼓浪屿以便建设旅游 设施, 如海底世界、大型商场等, 商业业态以本地小吃和 旅游纪念品为主。人口结构方面, 传统的熟人社会网络被 打破, 一方面是由于住房改革政策和工厂搬迁, 很多长期 生活在岛上的工人选择离开; 另一方面, 以安徽人为主体 的外地务工人员进入社区发展旅游业, 社区异质性开始出 现[3]。城市空间方面, 岛内陆续开辟了若干核心景点, 商 业化空间主要呈线性分布在东部、东南片区的钢琴码头至 龙头路、晃岩路到日光岩一带; 西南片区则修建了疗养院、 酒店等度假设施; 中部片区保持居住功能。 


\subsection{2. 异化期: 2003年-2009年}

政策方面，2003年鼓浪屿撤区，成立鼓浪屿-万石山 风景名胜区管委会, “强景弱城”的政策地位进一步强化。 2007 年, 为推动旅游业发展, 提升夜间旅游活力, 管委会 施行晚间轮渡票价减免优惠政策。2008年出台《鼓浪屿家 庭旅馆管理办法》以扶持发展家庭旅馆, 推动鼓浪屿岛上 原居住空间转变为商业空间。经济社会方面，这一时期岛 上过夜游客激增, 较管委会成立之前年游客量翻番, 与之 配套的餐饮、酒吧、KTV、住宿等快速发展。人口结构方 面, 鼓浪屿户籍人口首次出现快速下降趋势, 由 2005 年的 1.6 万人骤减至 2009 年的 1.4 万人, 本地居民迁出, 外来务 工人员增多, 社区异质性进一步增强。城市空间方面, 旅 游商业化空间仍然以龙头路为核心发展, 开始由主要街巷 向内部次要街巷蔓延, 逐渐形成龙头路商业片区; 龙头路 商业片区开始沿中华路、福建路向菽庄花园、皓月园等主 要景点延伸; 内厝澳、泉州路等跨片区联系的主要街巷开 始商业化。此外少量家庭旅馆分散全岛。

\subsection{3. 脆弱期：2009-2014年}

政策方面，福厦高铁、厦深高铁的陆续开通使得厦门 区域交通格局得到改善, 并成为鼓浪屿旅游发展新契机, 这一时期游客数量激增, 在2009年至2012年这三年间边飞 速实现年游客量翻番, 达到 1100 万人次。经济社会方面, 游客的激增带来大规模的商业投资, 在高额租金的压力下, 面向居民的日常生活服务业态逐渐转变为高利润的旅游 业态，一时间居民很难找到洗衣店、五金店、药店等日常 服务类商店，而具有小资情节的网红店却被竞相模仿 [3]。 人口结构方面，社区主体进一步被东北、江浙和省内地区 投资者替代, 基于社区熟人网络的社会交往开始演变为商
业利益的社会关系, 户籍人口以每年约 $5 \%$ 的速度继续衰 减, 而主要的服务业从业人员也逐年减少, 说明鼓浪屿的 商业活动已经达到饱和甚至过度。城市空间方面, 2012 年内厝澳码头、三丘田码头相继完成修建和扩建, 改变了 鼓浪屿旅游的“东热西冷”格局, 龙头路的商业片区开始向 以海坛路、市场路、中华路等街巷为代表的中部片区转移, 鼓浪屿的东中西部社区都受到了商业空间的严重冲击, 甚 至会有蔓延全岛的趋势。

\subsection{4. 恢复期：2014年至今}

政策方面，2012年《厦门经济特区鼓浪屿文化遗产保 护条例》的出台标志着鼓浪屿走上“人文回归”的道路, 2014年开始，鼓浪屿实行游客“限流”政策，规定每日最大 承载量为 5 万人次, 比《鼓浪屿-万石山风景名胜区总体规 划（2010-2025）》规定的6.5万人次减少近三分之一，极 大缓和了鼓浪屿有限空间内的旅游承载压力。2017年, 鼓 浪屿成功登录世界文化遗产, 逐渐回归原真性与完整性保 护的本质与要求。经济社会方面, 2013年出台的《鼓浪屿 商业网点规划》严格控制商业发展规模和空间拓展, 为社 区居民提供多样化、高质量服务的商业业态。从人口上看, 这一时期鼓浪屿户籍人口减速放缓, 并且从2017年开始鼓 浪屿人口迁入呈现上升趋势, 并逐渐赶超迁出人口数量。 然而, 作为现如今鼓浪屿的支柱产业, 旅游开发与历史社 区保护之间的矛盾仍旧非常尖锐, 根据《鼓浪屿文化遗产 地调研报告（2017）》中对游客、居民、商家的调查, 龙 头路片区和日光岩景区作为商业中心和核心旅游景点, 人 声嘈杂、卫生较差、空间拥堵的情况仍较为严重, 居民与 商家之间由于自身利益的问题也在物价、游客数量等方面 分歧较大。

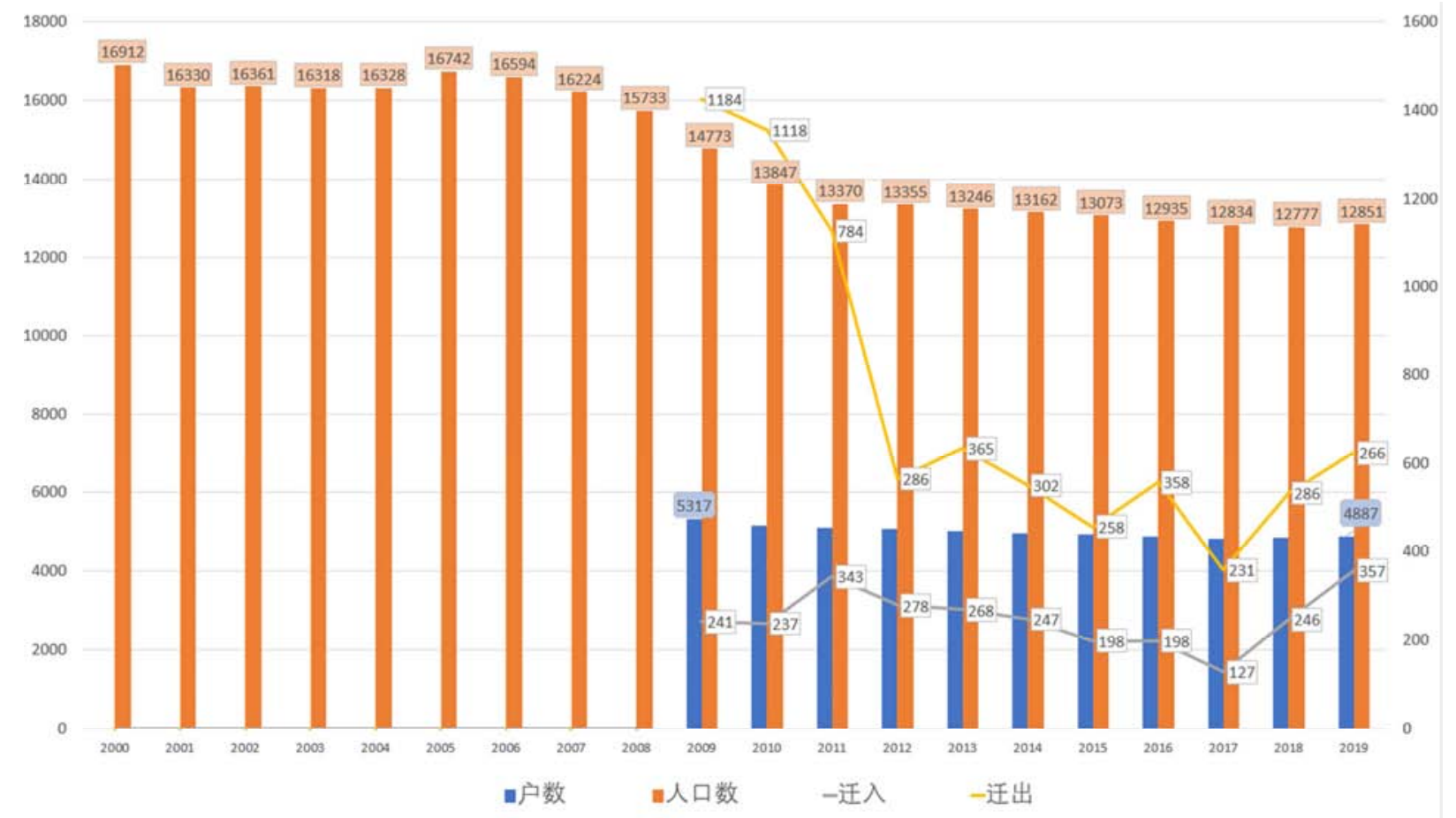

图5 2000-2019年鼓浪屿街道户籍人口变化情况。 
1400
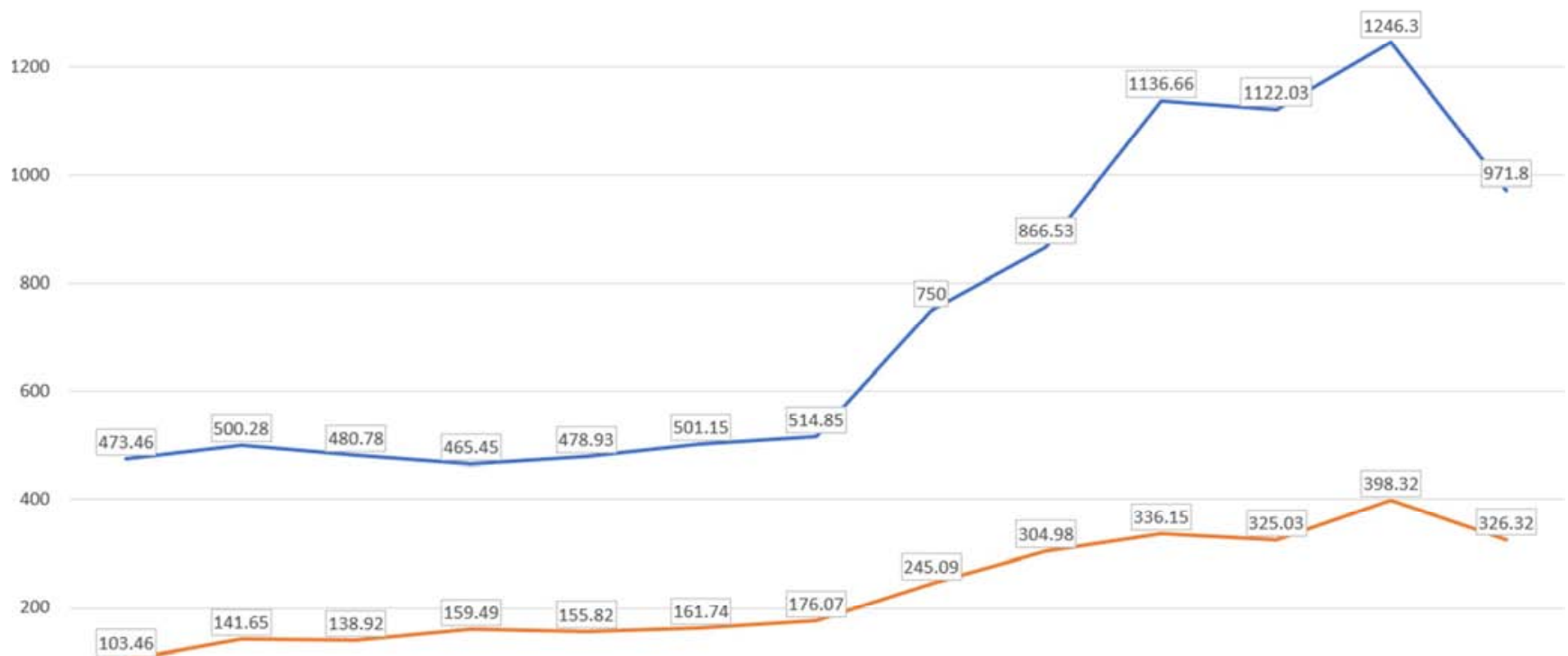

0

\begin{tabular}{|c|c|c|c|c|c|c|c|c|c|c|c|c|}
\hline 2003 & 2004 & 2005 & 2006 & 2007 & 2008 & 2009 & 2010 & 2011 & 2012 & 2013 & 2014 & 2015 \\
\hline
\end{tabular}

图6 2003-2015年鼓浪屿游客接待量变化。

300000

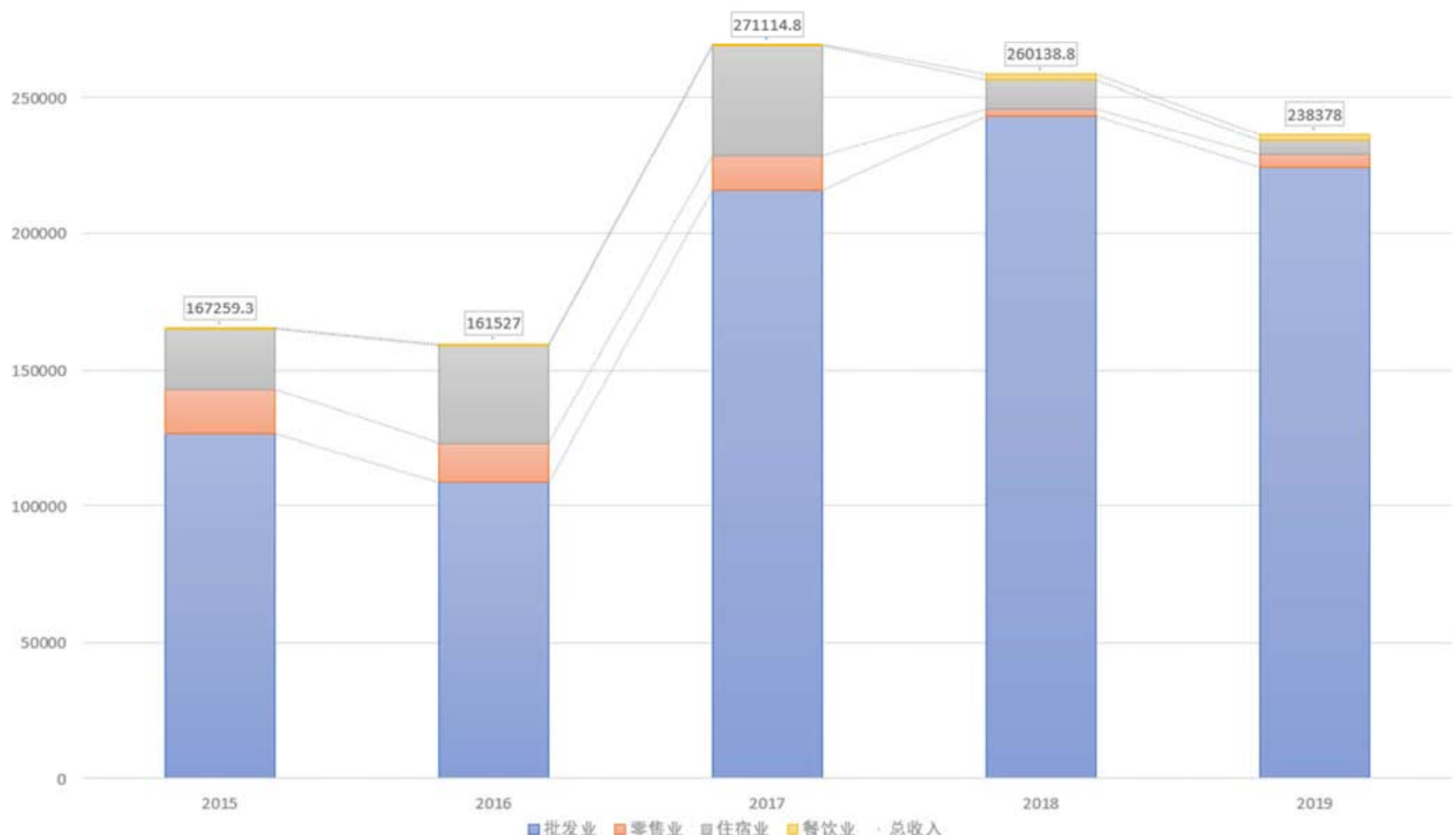

图7 2015-2019年鼓浪屿街道批零住餐四产业营业收入（万元）变化情况。 


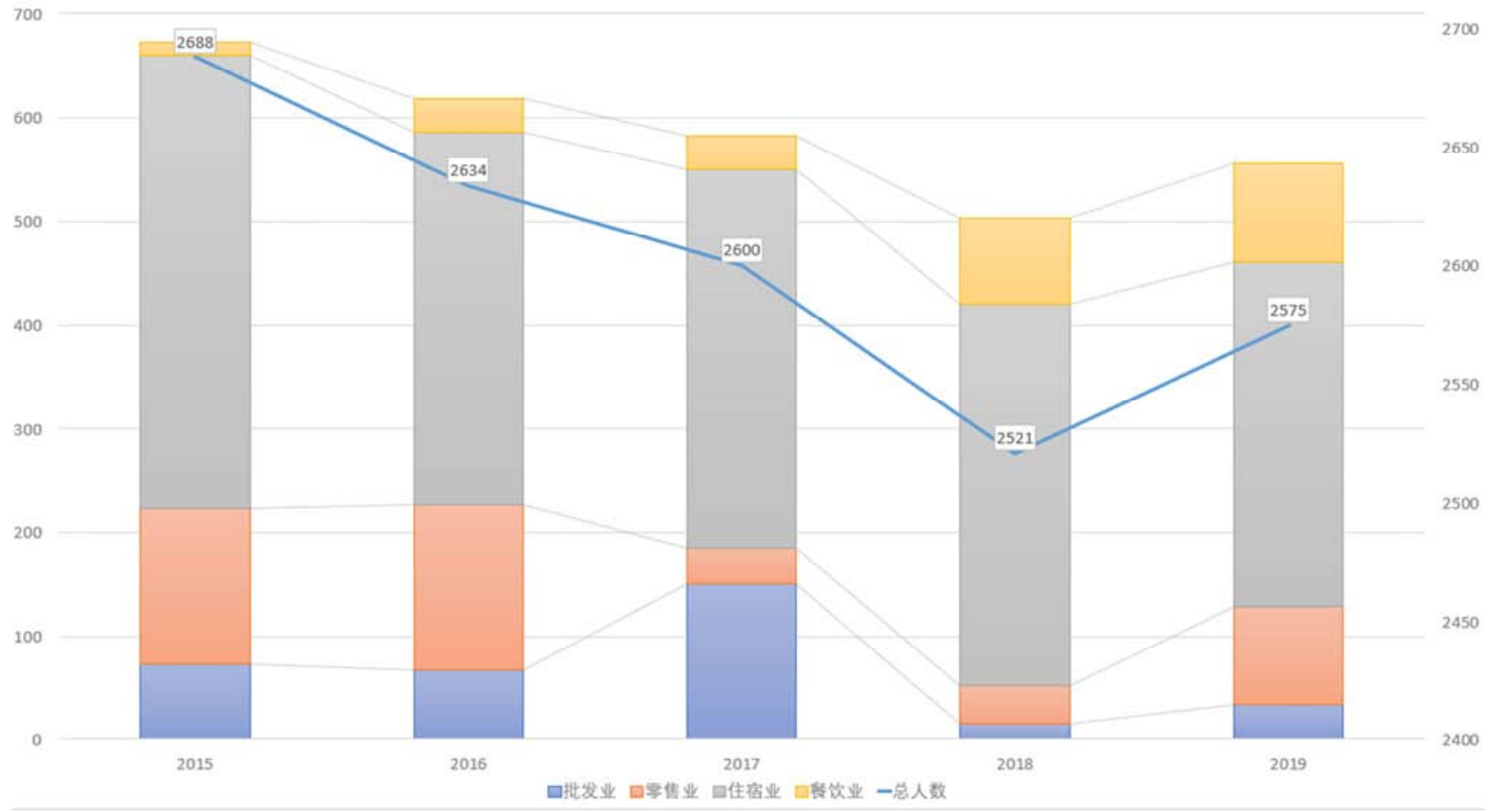

图8 2015-2019年鼓浪屿街道批零住餐四产业从业人数变化情况。
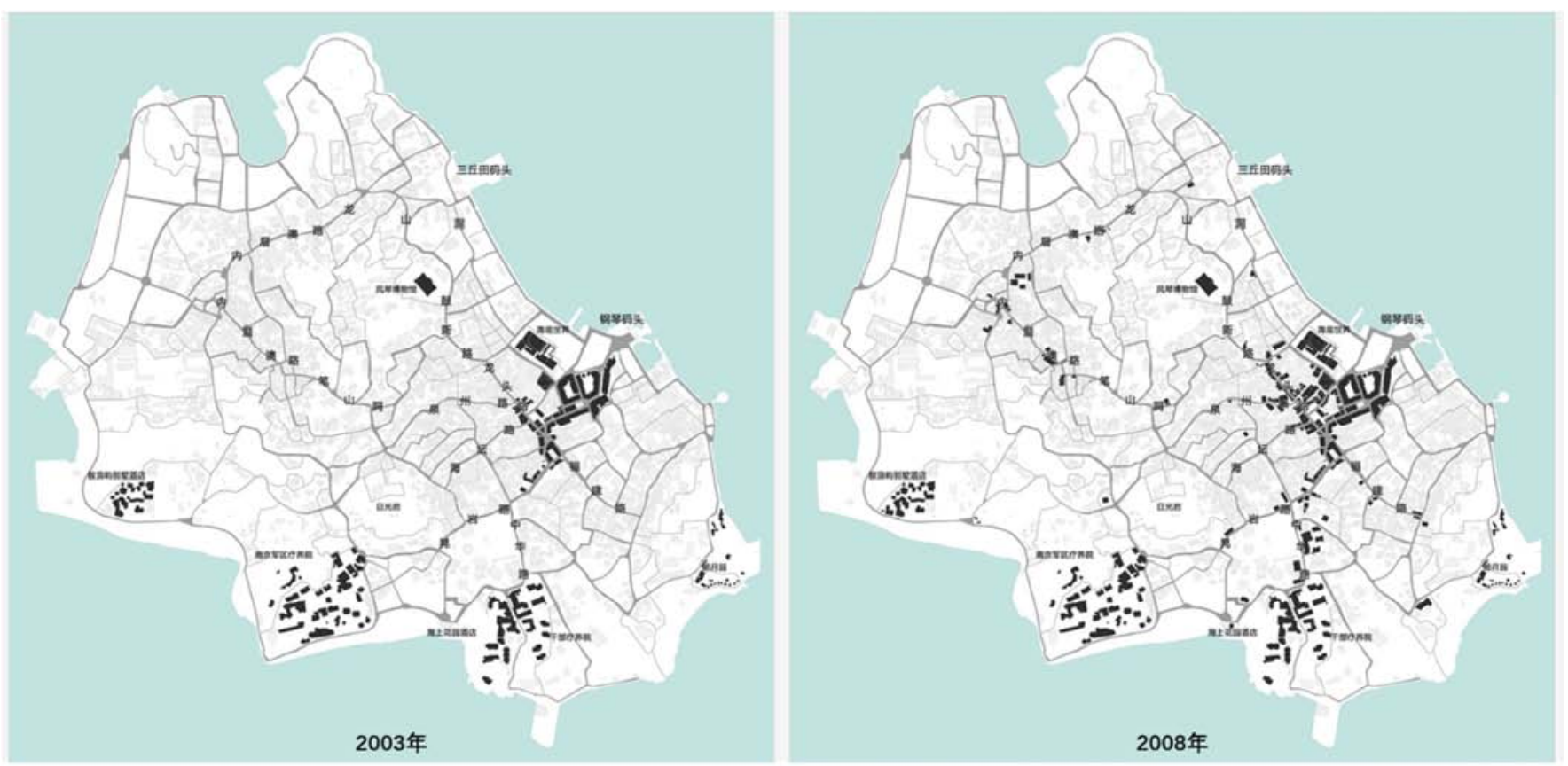


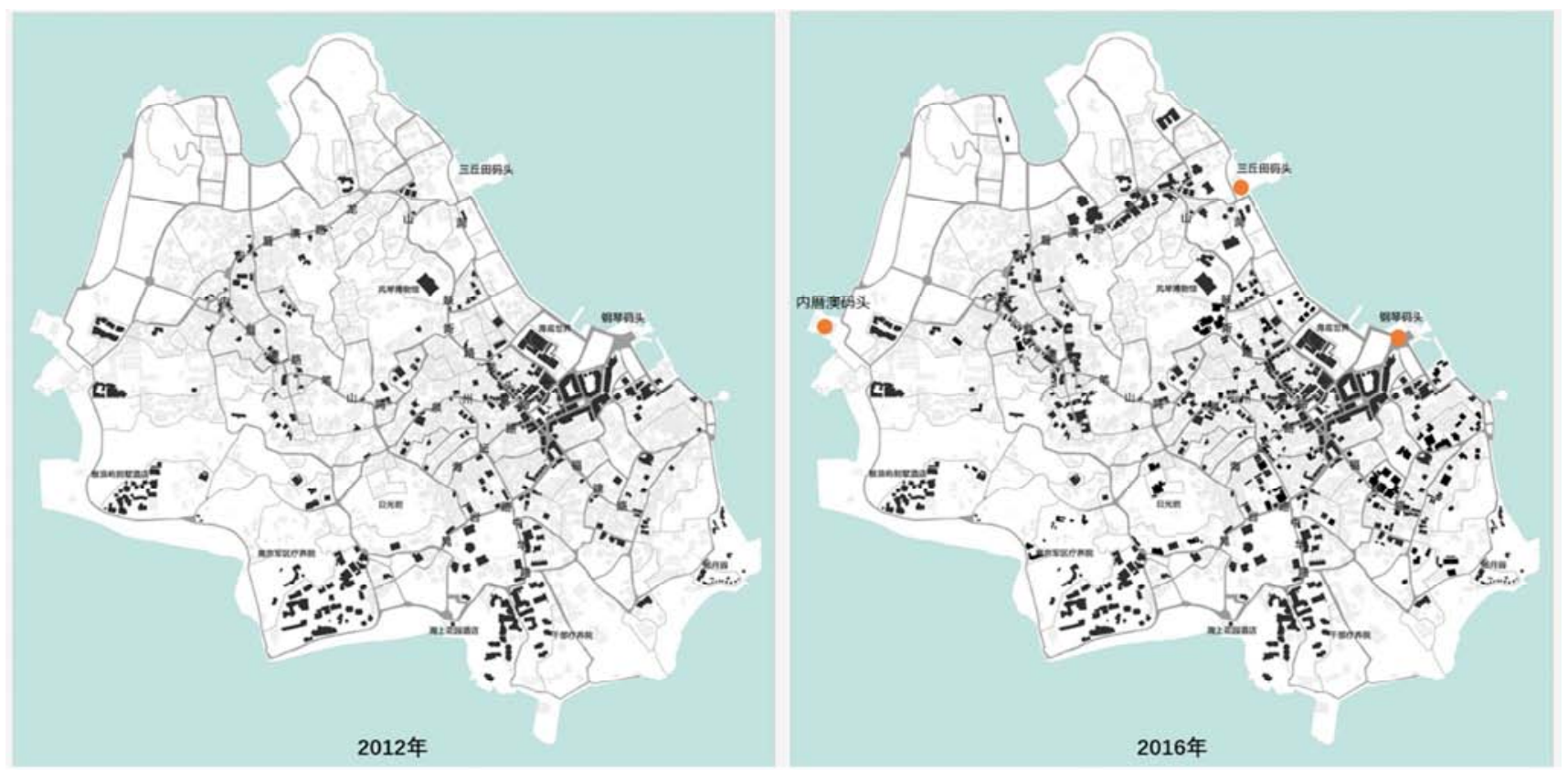

图9 鼓浪屿四个时期商业空间演变进程。

\section{2. 当前鼓浪屿社区发展面临的危机}

\subsection{1. 社区主体更替, 地域文化认同感降低}

鼓浪屿地域文化是本地居民在历史长期发展过程中 不断延续、演进形成的生活方式、价值观念、思想文化等 的总和，居民作为鼓浪屿历史社区的显性主体，是其地域 文化创造和传承的活的载体 [13]。然而, 随着旅游景区地 位的强化, 旅游人口的逐年激增, 产业搬迁、人口疏解和 撤区并市等政策的实施，加之厦门本岛中心城区的快速发 展, 就业吸引力加强, 吸引了大部分年轻、高素质和高收 入人才搬离出鼓浪屿, 留下来的是老年人、低收入人口和 外来流动人口。鼓浪屿户籍人口从 1985 年的 2.37 万人衰减
到 1.3 万人, 目前实际居住人口不足 7000 人。在未来几十 年内, 鼓浪屿社区主体的更替成为必然的趋势, 在未来如 何处理新主体与原住民的关系, 培育共同的社区认同感, 参与社区发展与保护等方面是重点关注的议题。

\subsection{2. 社区经济系统韧性降低}

大众媒介的兴起，使得大量低成本、快营销的外部资 本注入鼓浪屿社区内部，在混乱的旅游消费市场中，信息 网络、流动资本的巨资营销与无序化竞争，击溃了散兵游 勇的在地生产个体, 比如手工鱼丸、馅饼等本地产品被外 来资本抄袭、变种，原住民的小成本经营在大浪前不堪一 击。
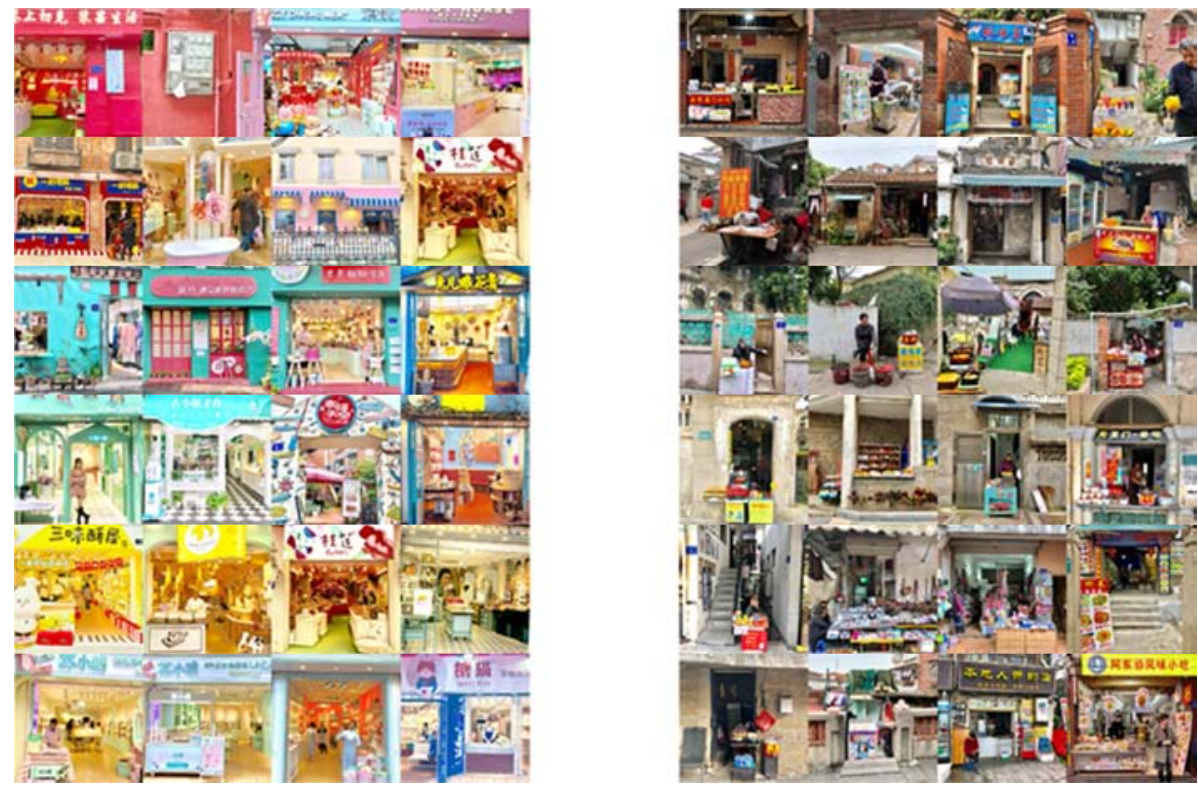

图10 鼓浪屿商业业态对比。 
鼓浪屿自身原有的社区经济系统被逐渐侵占, 取而代 之的是大力发展风景旅游区的开发建设, 如土特产销售、 海洋生物保护园、植物园等游览主体, 与鼓浪屿登录世界 文化遗产的“历史国际社区”主体的文化价值关联较弱, 缺
乏具有内发性更新驱动力和地域独特性的产业。这种后来 居上的以旅游消费为基础的社区经济系统, 商业同质化倾 向严重, 其运行依赖于旅游创收和政府注资, 无法承受外 部旅游市场环境变化或者内部经济转型的冲击。

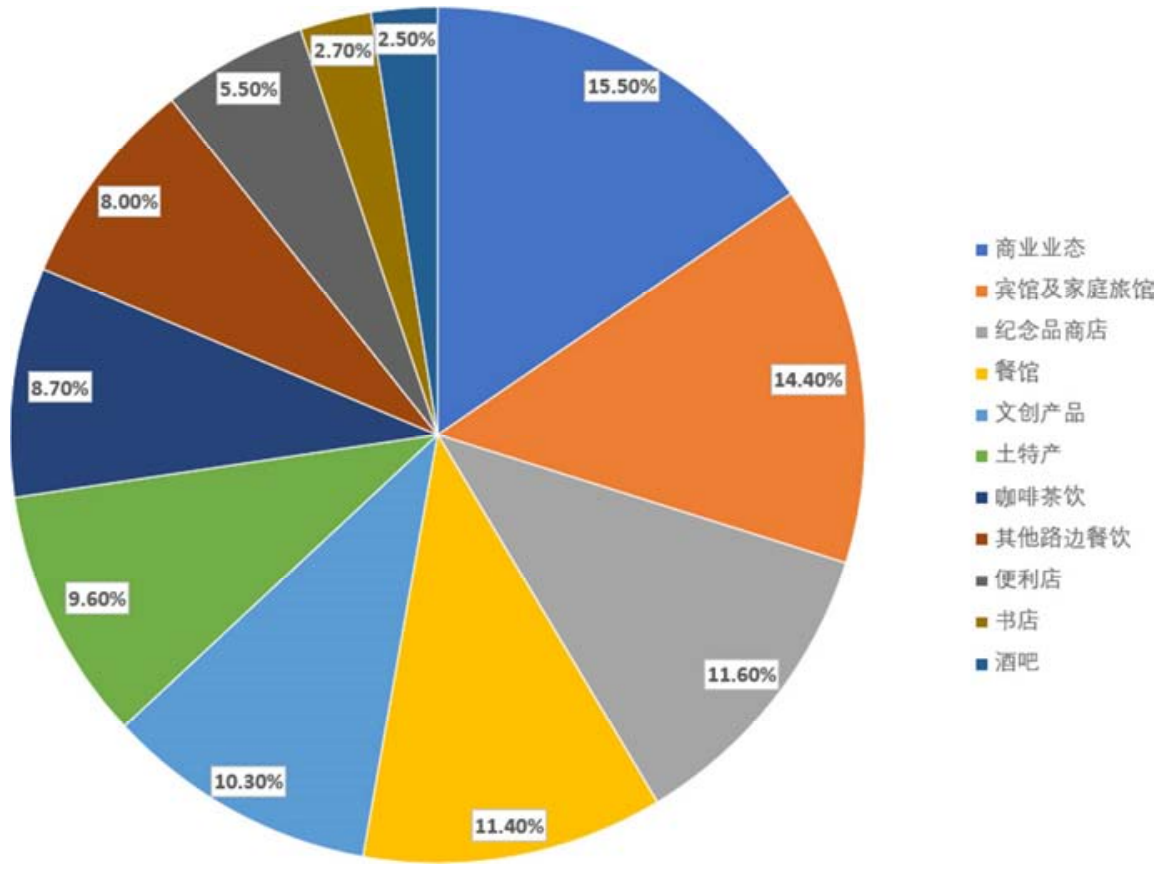

图11 鼓浪屿商业业态结构。

\subsection{3. 城市空间割裂对立}

当前, 鼓浪屿通过控制游客容量、分散游客与居民使 用空间的方式来调整空间资源配置。延续历史肌理, 笔架 山-英雄山山脉自然地将城市空间分割为东西两边, 在政 府有意的政策控制与规划下, 逐渐发展成为东部承载旅游 商业活动, 西部满足本地居民日常生活的城市空间格局。 这虽然在一定程度上解决了居民与游客的矛盾, 但也造成 旅游消费空间的单一化、同质化，仅保留了物质环境基础 而失去了鼓浪屿历史国际社区独特的多元文化内涵。

\subsection{4. 缺乏有效实施管理}

鼓浪屿的开发保护在我国历史文化遗产保护工作中 开展较早, 从解放初期便不断出台相关政策。然而在社会 转型期背景下, 行业法规建设、执行过程、社会监督、社 会建立共识等过程相对之后, 资本追求短期收益, 在实际 操作过程中对历史遗产的价值往往缺乏普遍认识[14]。同 时, 由于鼓浪屿景区与社区并行的特殊性质，风景区管委 会与社区街道办事处在某些管理问题上存在权责交叉的 矛盾。

\section{4. 探索：鼓浪屿历史社区的保护与发展}

\section{1. 鼓浪屿社区发展动力机制}

美国社会学家F·法林顿于1915年在《社区发展：将小 城镇建成更加适宜生活和经营的地方》一书中首次提出社
区发展（Community Development）的概念, 其后在英、 美、法等工业化国家开展的“睦邻运动”旨在培养居民自治 和互助精神, 在一定程度上推动了社区经济与社会同步发 展。在社区发展规划方法论中, 社区分析就社区各要素的 相互关系进行探讨, 寻找不同层面的相关问题, 从而聚焦 主要矛盾以制定规划的重点和突破口[15]。

表1 社区分析各层面要素。

\begin{tabular}{lll}
\hline 社区组成 & 介入层面 & 反映特征 \\
\hline 主体 & 自然人层面 & 人群自然结构属性 \\
社区人群特征 & 社区人层面 & 人群社会阶层属性 \\
隐体 & 行为方式 & 人群生活方式 \\
社区意识互动 & 精神层面 & 社区精神凝聚 \\
连体 & 互动层面 & 社区人群互动 \\
社区组织管理 & 政府层面 & 政府管理、服务及保障 \\
载体 & 政府层面 & 非政府管理、服务 \\
社区物质空间 & 空间布局 & 社区空间环境 \\
\hline
\end{tabular}

资料来源: 赵民,赵蔚编著.社区发展规划 理论与实践 $[\mathrm{M}]$. 北京:中国建筑 工业出版社.2003.41.

笔者基于社区发展理论分析模型, 结合上文对鼓浪屿 历史社区在旅游开发影响下不同演化阶段的研究, 构建出 由显性主体、隐性主体、空间载体及机制连体构成的鼓浪 屿历史社区发展动力机制模型。 


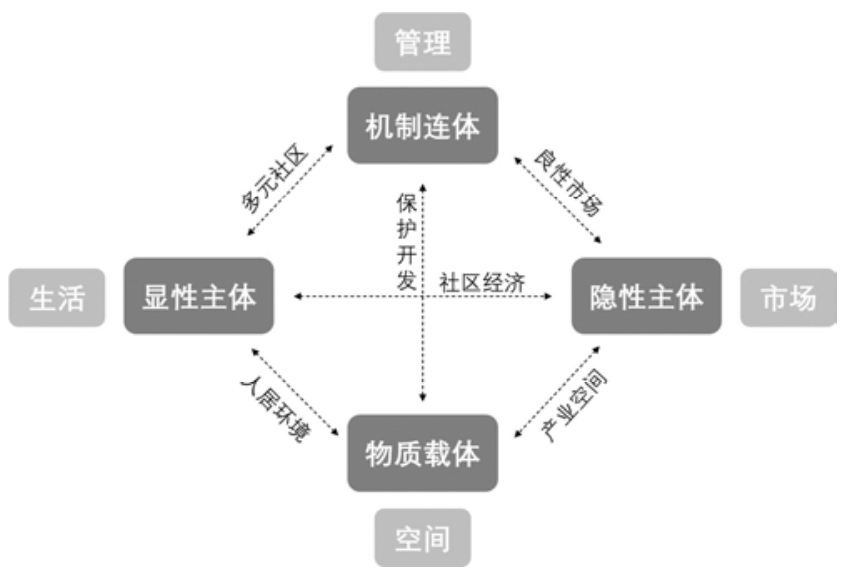

图12 鼓浪屿历史社区发展动力机制模型。

显性主体即生活在社区中的人及其生活方式的总和。 鼓浪屿历史国际社区具有文化多元性，闽南文化、海洋文 化、汉文化、异质文化、宗教文化等，具有深厚的民族特 性、宽容的文化包容力和强大的自我更新能力，有力推动 了鼓浪屿在城市建设、社区自治、经济发展、文化创新的 近代化变革。但旅游商业化浪潮却在不断冲击着传统的城 市与乡村社会, 改变着社区结构与社会关系。隐性主体即 是资本市场。追求经济利益是地区发展的根本动力，鼓浪 屿转型旅游开发是适应时代背景与经济发展的需求, 具有 重要的现实意义, 应当通过旅游业来拉动、促进鼓浪屿其 他产业之间的融合互动发展, 然而当前旅游开发与社区生 活的矛盾日益突出, 过度商业化问题保守诟病。空间载体 即是城市物质空间环境。鼓浪屿不仅是需要进行原真性与 完整性保护的世界文化遗产, 也是要满足居民生活需求和 产业发展需求的高质量人居环境与产业空间。机制连体包 含政策制定与运行管理, 需要政府、居民、社会资本等多 方协同。历史遗产保护应当突出政府干预的强制作用, 避 免资本盲目逐利而对遗产造成破坏。

\section{2. 鼓浪屿历史社区的保护与发展策略}

\subsection{1. 基于在地文化进行产业转型, 实现社区经济系统可 持续发展}

过去几十年，鼓浪屿作为风景名胜区的经济发展带动 整个厦门市的旅游经济发展, 同时, 经济效益的“转移”现 象也愈发明显。这并非说明鼓浪屿失去了旅游头部价值, 站在全局角度而言, 风景名胜区与城市二者的利益是一个 统一体, 符合调控区内经济、发展边缘经济、带动地区经 济的整体经济策略。鼓浪屿作为风景旅游区, 应加强与隔 海相望的厦门城市功能区之间的互动, 实现差异化发展, 让城区尽可能多地承担风景名胜区服务配套需求转移的功 能, 各司其职, 发挥联动效应和最大效益配置, 共同发展。

与周边地区相比, 鼓浪屿岛屿型环境的产业发展劣势 主要在于受限于遗产保护, 用地紧张, 无法满足一般城市 空间能承载的大规模在地生产的空间需求和人力需求。同 时, 鼓浪屿的发展优势在于自然环境、品牌溢价和游客市 场, 能作为区域产业的展示啀窗。一方面, 鼓浪屿可以从 食品、文化产业入手发展在地生产，创造岗位。充分利用 集美大学、厦门大学等艺术创作资源, 为艺术工作者提供
政策资金支持，吸引艺术家人群驻岛。另一方面，整合周 边区域资源, 将生产活动作为一种景观以丰富游客体验。

\subsection{2. 优化人口结构, 促进社区多元化发展}

在整合区域资源进行可持续性的产业转型基础上, 发 展文创工作者、疗养型驻岛游客、社区居民等多元化社区。 文创工作者群体能填补教育产业短板, 刺激文创产业发展, 带动文化振兴, 把鼓浪屿的文化气质、普遍价值进行进一 步挖掘和升华; 利用自然风光资源和空置建筑, 拉动疗养 产业阐发, 培养长期居住型游客。以上二者创造就业岗位, 带动社区消费, 缓解人口下降、老龄化的趋势, 从而营造 多元化的常住型人群社区, 丰富居民社区的功能, 重新焕 活市井生活中的生命力。

需要注意的是, 以社区为先导的历史文化遗产振兴容 易出现“绅士化”的现象, 商业活动较多、经济水平发展较 快的街区极易取代经济发展较慢的区域, 从而加速社会人 口结构的不平衡变化[16]。而对于目前的鼓浪屿社区而言, 优先多元社区发展有一定的现实意义。首先, 鼓浪屿的社 区正在面临人口衰败、设施老旧等困境, 街区活力丧失, 一定程度的“绅士化”能够提升社区价值, 促进街区发展。 其次, 将疗养、艺术等相关业态引入传统单一居住功能的 社区, 满足了鼓浪屿作为文化旅游城市的功能需要。实际 上, 将居住、商业、文化等活动相结合的复合型街区振兴, 才能促进鼓浪屿的全面协调发展。

\subsection{3. 整合利用城市空间, 提升人居环境水平}

产业转型与社区人口结构调整, 使得鼓浪屿历史街区 多样化发展, 保证文化振兴的活力源头, 为改变当前鼓浪 屿东密西疏、东西割裂的城市旅游空间格局提供了可能。

一. 丰富旅游体验内容。在建立全岛历史文化资源信 息库的基础上, 对旅游资源进行分类整合, 挖掘文化旅游 的多样性, 打造多样化的旅游路线, 避免游客体验内容单 一造成旅游链条产业过度快销化。二, 优化交通, 实现时 空分流。优化全岛交通体系, 在环岛路增设小型环保型公 交车站, 疏通环岛路与居民社区的交通联系要道, 在坚持 做到“绿色慢岛”的基础上提升交通便利性。通过岛内分流、 岛城联动、日夜游线等方式, 实现旅游人流的平衡分布, 结合多码头多航线组合, 形成有效的人流控制机制, 实现 时空分流。三，公共服务设施优化。在遵循保护区建设政 策的基础上, 充分利用空置资源, 增设快递点、急救站、 环卫点等公共设施, 促进社会公平。

\subsection{4. 构建多方协同管理机制与利益分配机制}

历史文化遗产保护, 是一项长期工作, 需要通过稳定、 弹性、公众参与的方式动态追踪保护过程, 这需要构建多 方协同的管理机制。将历史文化遗产保护从过去单一技术 层面的精英规划与执行, 向多方协同的公共决策转变 [17]。 鼓浪屿现有的管理机构存在二元体制、地位不对等的问题。 鼓浪屿地理面积小, 加之已经申遗成功, 理应建立统一的 管理机构, 加强对历史社区的保护。同时要推行社区自治 管理, 建立多元的协会, 如商家协会、民宿协会、公共议 事理事会等, 实现社区自治共治, 增强社区居民主人翁意 识和社区认同感和归属感。 
在现有的旅游发展模式下, 旅游开发的经济收益属于 政府和开发商、商家共同所有，本地居民不仅不能分享利 益, 还要忍受旅游带来的负面因素, 这直接导致了居民社 区认同感的缺失。因此, 要建立一个公平的利益分配机制, 政府将旅游的门票收入和商业税收按一定比例反哺社区, 用于改善公共服务设施、提供生活补助金、交通费减免等。 让社区居民共享旅游发展的成果, 以提高对社区的认同感 和文化遗产保护的积极性。

\section{5. 结语}

鼓浪屿历史国际社区的遗产价值依托于广义的文化 环境, 包括物质空间要素与涉及经济、社会、文化的非物 质内容。自 20 世纪 80 年代末发展旅游业以来, 鼓浪屿历史 社区在旅游开发影响下先后经历了发展期、异化期、脆弱 期、恢复期，各时期在政策、经济、人口结构、城市空间 四个维度体现出鲜明的特点。过去单一注重空间保护的规 划概念，使得鼓浪屿的价值资源被人为区分主体与附属部 分, 过分重视与旅游观光相关的城市空间的保护，而忽视 作为鼓浪屿活态基因的社区文化、人文文化的传承。而鼓 浪屿申报世界遗产地目的之一便在于借助申遗契机加强 社区参与、达到社区复兴的目的 [3]。

当前, 鼓浪屿正处于世界文化遗产旅游社区恢复时期, 但仍然面临由地域文化认同低、社区经济系统㓞性低、城 市空间对立割裂、缺乏有效实施管理等带来的危机。基于 社区发展规划理论对危机溯源, 构建由显性主体、隐性主 体、空间载体及机制连体构成的鼓浪屿历史社区发展动力 机制模型, 从而探讨鼓浪屿历史社区保护与发展的可行路 径。我国目前文化遗产地众多, 既要通过各种经济刺激手 段例如发展旅游业以带动地区经济发展, 也要预防过度商 业化对文化遗产的内涵与价值造成破坏, 保证文化遗产地 在“后遗产”时代实现可持续发展将会是具有挑战性与持 久性的课题。

\section{参考文献}

[1] 吕宁,魏青.旅游模式转变影响下的社会经济效益评价对鼓浪屿入遗效应的再思考 [J]. 中国文化遗 产,2020(01):32-40. 2009.11.
[2] 赵刚. 旅游城镇社区发展调查与对策研究——鼓浪屿为 例 [C]. 中国城市规划学会.城乡治理与规划改革—-2014 中国城市规划年会论文集（08 城市文化）.中国城市规划 学会:中国城市规划学会, 2014:157-165.

[3] 吕宁,魏青,钱毅,孙燕.鼓浪屿价值体系研究[J].中国文化遗 产,2017(04):4-15.

[4] 刘宁. 申遗背景下的鼓浪屿文化遗产价值综合保护体系[A] 中国城市规划学会、沈阳市人民政府.规划 60 年: 成就与挑 战—-2016中国城市规划年会论文集（08城市文化）[C]. 中国城市规划学会、沈阳市人民政府: 中国城市规划学 会,2016:9.

[5] 曾艾依然. 过度旅游压力下的旅游社区韧性研究[D].北京 林业大学,2020.

[6] 欧阳邦.旅游商业化影响下的鼓浪屿历史城镇社区发展研 究[D].华侨大学, 2018.

[7] 厦门市鼓浪屿-万石山风景名胜区管理委员会.鼓浪屿商业 网点规划[R].2013.

[8] 厦门市人民政府. 鼓浪屿文化遗产地保护管理规划 [R]. 2014.

[9] 厦门市人民政府.鼓浪屿历史文化街区保护规划[R]. 2014.

[10] 厦门市鼓浪屿-万石山风景名胜管委会.中国世界遗产预备 名录申报文本：鼓浪屿[R].2009.11.

[11] 厦门市人民政府.《鼓浪屿-万石山风景区总体规划》 $[R]$. 2017.

[12] 厦门市思明 区 经济社会年鉴 [ER/OL]. http://www.siming.gov.cn/zjsm/sjfb/nj/.2012-2020.

[13] 苏斌. 鼓浪屿的文化传承危机与对策[D].华侨大学,2014.

[14] 沈海虹. “集体选择”视野下的城市遗产保护研究[D]. 同济大 学, 2006 .

[15] 赵民,赵蔚编著.社区发展规划 理论与实践[M].北京:中国建 筑工业出版社.2003.

[16] 王唯山.鼓浪屿历史街区再生的规划思考一一结合鼓浪屿 龙头路街区调查 $[\mathrm{J}]$.建筑与文化,2008(03):96-101.

[17] 阳建强.基于城市发展机制的历史文化名城保护 [J].城市发 展研究,2009,16(11):139-142. 